\title{
Ocorrência de leishmaniose tegumentar em cães de área endêmica no Estado do Paraná
}

\author{
[Occurrence of cutaneous leishmaniasis in dogs of endemic area, Paraná State] \\ E. Pittner, E. Voltarelli, T.F. Perles, S.M.A.A. Arraes, T.G.V. Silveira, M.V.C. Lonardoni* \\ Universidade Estadual de Maringá \\ Avenida Colombo, 5790 \\ 87020-900 - Maringá, PR
}

\begin{abstract}
RESUMO
Investigou-se a infecção por parasitas do complexo Leishmania braziliensis em 50 cães da cidade de Maringá, PR, onde ocorreram casos humanos de leishmaniose tegumentar americana (LTA), entre agosto e dezembro de 2006. Os casos humanos de LTA ocorreram nos anos de 2003 a 2004. Nenhum animal apresentou lesão, mas $12(24,0 \%)$ tinham sorologia e/ou PCR positivas, e a positividade tanto da IFI como da PCR foi de $14,0 \%$. Trinta e cinco animais eram de residências, e oito deles $(22,8 \%)$ tiveram testes laboratoriais para LTA positivos. Os outros 15 eram cães errantes, sendo que quatro deles (26,7\%) apresentaram PCR positiva. A presença de animais com infecção assintomática por Leishmania em área onde a LTA é endêmica pode ser um indicador do potencial de sua transmissão para o homem e uma referência para a implantação de medidas de controle e prevenção da doença.
\end{abstract}

Palavras-chave: cão, homem, Leishmania braziliensis, leishmaniose tegumentar americana

\begin{abstract}
The infection by Leishmania braziliensis complex was studied in 50 dogs from Maringá, $P R$, where American Cutaneous Leishmaniasis (ACL) in humans have been detected. Data were collected from August to December 2006 in an area in which ACL cases in humans were reported from 2003 to 2004. Indirect immunofluorescent test (IIF) and polymerase chain reaction (PCR) were applied. No lesions were found in the animals, although 12 (24.0\%) had positive IIF and/or PCR. Positiveness was $14.0 \%$ for IIF and PCR. Lab tests showed that eight (22.8\%) out of the 35 home animals were ACL positive. The other 15 animals were stray dogs, out of which four (26.7\%) were PCR positive. The appearance of asymptomatic Leishmania-infected dogs in an ACL endemic area may be an indicator of $A C L$ transmission potential for humans and a reference for the establishment of control measures and disease prevention.
\end{abstract}

Keywords: dog, Leishmania braziliensis, American Cutaneous Leishmaniasis

\section{INTRODUÇÃO}

No Paraná, a leishmaniose tegumentar americana (LTA) tem caráter endêmico, com notificação em 276 dos 399 municípios, principalmente no norte e oeste deste Estado (Lima et al., 2002). A leishmaniose tegumentar está presente em duas áreas geográficas distintas do Paraná e apresenta comportamento epidemiológico diferente. Em uma das áreas, localizada no Vale do Rio
Ribeira, a doença é conhecida desde o começo do século XX. Na outra, no norte do Paraná, têmse assinalado casos de LTA desde o início de sua colonização (Castro et al., 2002). No Estado do Paraná, os casos descritos têm como agente a Leishmania (Viannia) braziliensis (Silveira et al., 1996; 1999).

A domiciliação da transmissão da LTA tem sido sugerida pela associação observada entre a

Recebido em 4 de dezembro de 2008

Aceito em 23 de abril de 2009

Autor para correspondência (corresponding author):

E-mail: mvclonardoni@uem.br 
infecção em indivíduos de ambos os sexos, de diferentes faixas etárias, e a de animais domésticos, como cães e equídeos, em ambientes peridomésticos, onde são capturados flebotomíneos (Madeira et al., 2003; Serra et al., 2003; Zanzarini et al., 2005). Como a transmissão da LTA tem aumentado no ambiente doméstico e há registros de infecção em cães, cresce a suspeita de que esses animais possam atuar como reservatórios de Leishmania sp. (Reithinger et al., 1999). Vexenat et al. (1986) verificaram que Lutzomyia whitmani infectava-se com L. braziliensis quando alimentados em áreas ulceradas, mas não quando alimentados em áreas não ulceradas da pele de cães infectados. Pirmez et al. (1988) não conseguiram isolar o parasita da pele normal de cães e Rangel et al. (1990) mostraram que flebotomíneos alimentavam-se menos frequentemente em humanos e cães do que em equídeos. Assim, o papel do cão no ciclo doméstico de transmissão da LTA permanece polêmico.

A constatação da leishmaniose tegumentar canina sob as formas sintomática e subclínica em regiões onde também ocorreram casos humanos sugere que o cão pode representar algum papel na cadeia de transmissão da LTA (Santos et al., 2005), o que torna importante investigar a infecção por Leishmania sp. em cães, bem como relacioná-la com os casos de LTA humana. O objetivo deste trabalho foi investigar a infecção por parasitas do complexo L. braziliensis em cães da cidade de Maringá, PR, área endêmica, onde ocorreram casos humanos de LTA.

\section{MATERIAL E MÉTODOS}

No período de agosto a dezembro de 2006, foram estudados 50 cães do município de Maringá, PR, sendo 28 machos e 22 fêmeas, de várias idades, dos quais 15 eram errantes, capturados pelo Centro de Controle de Zoonoses, e 35 cães que viviam em residências do bairro Borba Gato. Neste bairro, que abriga um bosque de mata nativa, ocorreram casos humanos de LTA nos anos de 2003 e 2004.

As amostras foram obtidas após a contenção física dos animais. O sangue foi coletado pela punção da veia jugular ou cefálica, e uma parte $(3 \mathrm{~mL})$ foi dispensada em tubos contendo igual volume de $\mathrm{ACD}(0,48 \mathrm{~g}$ ácido cítrico, $1,32 \mathrm{~g}$ citrato de sódio, 1,47g glicose; em $100 \mathrm{~mL} \mathrm{H}_{2} \mathrm{O}$ ); posteriormente essas amostras foram divididas em alíquotas de $1,5 \mathrm{~mL}$ e mantidas a $-20^{\circ} \mathrm{C}$ até seu uso. Outra parte do sangue $(5 \mathrm{~mL})$ foi centrifugada, e o soro obtido foi armazenado a $20^{\circ} \mathrm{C}$, para posterior realização do teste de imunofluorescência indireta.

Para a coleta de material de lesão, após o exame físico foi feita a contenção do animal e, ao redor da área da lesão, foi aplicada lidocaína a $0,2 \%$ (diluída 1/10). As amostras foram obtidas por escarificação da borda interna de lesão e usadas para a confecção de esfregaços em lâminas de microscopia, que foram coradas pelo método de Giemsa. Os esfregaços foram analisados por microscopia para a pesquisa direta (PD) de formas amastigotas de Leishmania sp.

A reação de imunofluorescência indireta (IFI) foi realizada conforme descrito anteriormente (Silveira et al., 1996). Resumidamente, foram usadas formas promastigotas de L. (Viannia) braziliensis formolizadas e conjugado anti-IgG de cão-isotiocianato de fluoresceína ${ }^{1}$, no título 1/800. Inicialmente realizou-se uma reação qualitativa com os soros diluídos a 1/20 em solução salina tamponada com fosfato (SST). Os soros que se apresentaram positivos nesta reação foram então diluídos a partir de 1/20 em SST, em razão 2, para a determinação de seu título. Soros com títulos iguais ou superiores a 40 foram considerados significativos (Silveira et al., 1996).

A reação em cadeia da polimerase (PCR) foi realizada em amostras de sangue, e a extração de DNA de Leishmania foi feita com solução de isotiocianato de guanidina e fenol (GT). As amostras a serem extraídas foram descongeladas, lavadas duas vezes com SST e centrifugadas durante 15 minutos a $3.500 \mathrm{x}$ g. Ao sedimento acrescentaram-se $300 \mu \mathrm{L}$ de solução GT, homogeneizando-se por inversão durante um minuto, até que o sedimento fosse totalmente dissolvido. Após a adição de $50 \mu \mathrm{L}$ de clorofórmio gelado, o tubo foi agitado por inversão, delicadamente. Centrifugou-se a 9.300 $\mathrm{x} g$ durante 10 minutos, e o sobrenadante foi transferido para outro tubo contendo $300 \mu 1$ de etanol absoluto gelado. Após a homogeneização, centrifugou-se a $9.300 \times \mathrm{g}$ durante 10 minutos, e o sedimento foi lavado duas vezes com $300 \mu \mathrm{L}$ de etanol absoluto gelado. $\mathrm{O}$ sedimento foi seco em

${ }^{1}$ Sigma-Aldrich - St. Louis, EUA. 
banho-seco ${ }^{2}$ a $95^{\circ} \mathrm{C}$, adicionaram-se $50 \mu \mathrm{L}$ de tampão TE (1mL de Tris-base $10 \mathrm{mM}$, pH 8,0; $200 \mu \mathrm{L}$ de $\mathrm{Na}_{2}$ EDTA-H $\mathrm{H}_{2} \mathrm{O}$ 0,1mM. pH 8,0). A mistura foi incubada em agitador rotatório durante seis horas à temperatura ambiente para completa dissolução do sedimento e armazenada a $4^{\circ} \mathrm{C}$ para posterior amplificação.

Para a amplificação do DNA, foram utilizados os iniciadores LU-5A $\left(5^{\prime}\right.$ - TTT ATT GGT ATG CGA AAC TTC - 3') e LB-3C (5' - CGT SCC GAA CCC CGT GTC - 3') descritos por Harris et al. (1998), que amplificam o fragmento de 146-149 pares de base da sequência líder multicópia do gene do RNA do complexo $L$. braziliensis. A mistura de reação $(25 \mu \mathrm{L})$ continha $1 \mathrm{mM}$ de cada um dos iniciadores ${ }^{3}$, $0,2 \mathrm{mM} \mathrm{dNTP}^{2}, 1 \mathrm{U}$ de Taq DNA Polimerase ${ }^{2}$, $1,5 \mathrm{mM}$ de $\mathrm{MgCl}_{2}$, tampão da enzima e $5 \mu \mathrm{Lde}$ DNA molde. A amplificação do DNA foi feita no termociclador personal cycler ${ }^{4}$, utilizando-se aquecimento de $95^{\circ} \mathrm{C}$ durante cinco minutos. Posteriormente foram realizados 30 ciclos, cada um deles divididos em três etapas: desnaturação $\left(95^{\circ} \mathrm{C}-1,5\right.$ minuto), anelamento $\left(56^{\circ} \mathrm{C}-1,5\right.$ minuto) e polimerização $\left(72^{\circ} \mathrm{C}-2\right.$ minutos $) . \mathrm{O}$ material foi mantido a $72^{\circ} \mathrm{C}$ durante 10 minutos, e o produto amplificado foi estocado a $4^{\circ} \mathrm{C}$ até a sua análise. As amostras amplificadas foram submetidas à eletroforese em gel de agarose $2 \%$ contendo brometo de etídeo $0,1 \mu \mathrm{g} / \mathrm{mL}$, a $10-15$ $\mathrm{V} / \mathrm{cm}$, durante 25 minutos. Para cada seis amostras a serem amplificadas, foram adicionados um controle positivo e um controle negativo de amplificação. Após a corrida, a verificação da presença de bandas foi realizada em transiluminador ${ }^{5}$.

Esta pesquisa foi aprovada pelo Comitê de Conduta Ética no Uso de Animais em Experimentação da Universidade Estadual e Maringá, conforme o parecer 070/2005.

\section{RESULTADOS E DISCUSSÃO}

A cidade de Maringá é bastante arborizada e, segundo Silva e Loch (2006), parece seguir um traçado urbanístico, estabelecido pela

\footnotetext{
${ }^{2}$ Bioplus Ltda. (IT-2002) - São Paulo, Brasil.

${ }^{3}$ Invitrogen Corporation - Carlsbad, EUA.

${ }^{4}$ Biometra - Goettinger, Alemanha.

${ }^{5}$ Macro Vue UV-20, Hoefer Pharmacia - San Francisco,

EUA.
}

Companhia Melhoramentos do Norte do Paraná, inspirado no modelo da cidade-jardim do urbanista inglês Ebenezer Howard. Nas áreas urbanas da cidade, são mantidos bosques com resíduos preservados da floresta original que cobria a região há cerca de 60 anos. Estudo sobre a fauna de flebotomíneos em parque da cidade já detectou várias espécies desses insetos, com predomínio de Lutzomyia whitmani (Teodoro et al., 2003). A presença de vetores e de diversas espécies de animais silvestres, vivendo em estreito contato com a população humana nos bairros residenciais localizados em áreas próximas aos bosques, parece criar ambientes favoráveis à manutenção do ciclo de Leishmania e possibilitar a transmissão para o homem e para os animais domésticos.

Ao exame clínico, nenhum dos animais estudados apresentava lesão sugestiva de LTA, mas $12(24,0 \%)$ apresentaram sorologia e/ou PCR positivas. A positividade tanto da IFI como da PCR foi de $14,0 \%$, e dois animais apresentaram ambos os testes positivos.

Dos 35 procedentes de residências do bairro Borba Gato, oito $(22,8 \%)$ cães foram positivos aos testes laboratoriais para LTA, sendo a IFI positiva em seis, a PCR em três e a ambos os testes, positiva em um. Neste bairro, há um bosque de mata nativa e as residências são vizinhas das matas. Os moradores relataram que animais silvestres invadem suas residências e que seus cães entram na mata. Neste bairro, ocorreram 25 casos confirmados de LTA humana entre outubro de 2003 e dezembro de 2004 (Mangabeira et al., 2004). Os outros 15 eram cães errantes, dos quais quatro (26,7\%) apresentaram PCR positiva, e um IFI positiva.

A descrição da LTA em cães data do início do século, e a alta prevalência da doença em cães e equinos de áreas endêmicas, principalmente no Brasil e na Venezuela, parece implicar esses animais na cadeia de transmissão de Leishmania nos ambientes domiciliar e peridomiciliar (Madeira et al., 2003; Santos et al., 2005). No norte do Estado do Paraná, existem relatos da existência de alto percentual de cães infectados e/ou com sorologia positiva para Leishmania em áreas endêmicas de LTA humana (Lonardoni et al., 1993; Silveira et al., 1996; Zanzarini et al., 2005; Velásquez et al., 2006). 
O encontro de cães com testes de diagnóstico positivos, inclusive a PCR, em localidades onde a doença humana tem sido detectada simultaneamente, sugere a participação desses animais no ciclo de transmissão da LTA. Quatro $(26,6 \%)$ cães errantes e três $(8,5 \%)$ cães de residências do município apresentaram DNA de Leishmania do complexo L. braziliensis. Estudo anterior com cães errantes nessa mesma região detectou $37,0 \%$ deles positivos pela IFI e $66,3 \%$ positivos pela aglutinação direta (Lonardoni et al., 2006). A alta percentagem de cães com sorologia positiva e/ou presença de DNA de Leishmania indica que o parasita continua circulando nessa área, possibilitando a manutenção do ciclo de transmissão de LTA. Segundo Cunha et al. (2006), em estudo realizado em área endêmica no Estado do Ceará, a ocorrência de casos humanos de LTA está associada à presença de cães infectados. No entanto, desde a ocorrência do surto em 2003, não foram detectados novos casos humanos de LTA no bairro estudado.

Este estudo mostrou a presença de cães com infecção assintomática em área endêmica de LTA. Assim, o encontro destes animais poderia ser um indicador do potencial de transmissão da LTA para o homem e uma referência para a implantação de medidas de controle e prevenção da doença.

\section{REFERÊNCIAS BIBLIOGRÁFICAS}

CASTRO, E.A.; SOCCOL, V.T.; MEMBRIVE, $\mathrm{N}$. et al. E. Estudos das características epidemiológicas e clínicas de 332 casos de leishmaniose tegumentar americana notificados na região norte do Estado do Paraná de 1993 a 1998. Rev. Soc. Bras. Med. Trop., v.35, p.445452,2002

CUNHA, J.C.L.; LIMA, J.W.O.; POMPEU, M.M.L. Transmissão domiciliar de leishmaniose tegumentar e associação entre leishmaniose humana e canina, durante uma epidemia na Serra de Baturité, no Estado do Ceará, Brasil. Rev. Bras. Epidemiol., v.9, p.425-435, 2006.

HARRIS, E.; KROP, G.; BELLI, A. et al. Single-Step multiplex PCR assay for characterization of New World Leishmania complex. J. Clin. Microbiol., v.36, p.1989-1995, 1998.
LIMA, A.P.; MINELLI, L.; COMUNELLO, E. et al. Distribuição da leishmaniose tegumentar por imagens de sensoriamento remoto orbital, no Estado do Paraná, Sul do Brasil. An. Bras. Dermatol., v.77, p.681-692, 2002.

LONARDONI, M.V.C.; BERNAL, F.H.Z.; SILVEIRA, T.G.V. et al. Comparação entre a imunofluorescência indireta e aglutinação direta para o diagnóstico sorológico da leishmaniose tegumentar americana em cães errantes. Arq. Bras. Med. Vet. Zootec., v.58, p.1001-1008, 2006.

LONARDONI, M.V.C.; TEODORO, U.; ARRAES, S.M.A.A. et al. Nota sobre Leishmaniose canina no noroeste do Estado do Paraná, Sul do Brasil. Rev. Saúde Pública, v.27, p.378-379, 1993.

MADEIRA, M.F.; UCHÔA, C.M.A.; LEAL, C.A. et al. Leishmania (Viannia) braziliensis em cães naturalmente infectados. Rev. Soc. Bras. Med. Trop., v.36, p.551-555, 2003.

MANGABEIRA, H.N.; ROBERTO, A.C.B.S.; ZANZARINI, P.D. et al. Surto de leishmaniose tegumentar no Bairro Borba Gato, Maringá Paraná. In: MOSTRA INTEGRADA DE ENSINO, PESQUISA E EXTENSÃO, 2.; SIMPÓSIO DA APADEC, 5., 2004, Maringá. Anais... Maringá: UEM, 2004. (Resumo).

PIRMEZ, C.; COUTINHO, S.G.; MARZOCHI, M.C.A. et al. Canine american cutaneous leishmaniasis: a clinical an immunological study in dogs naturally infected with Leishmania (Viannia) braziliensis in an endemic area of Rio de Janeiro, Brazil. Am. J. Med. Hyg., v.38, p.52$58,1988$.

RANGEL, E.F.; AZEVEDO, A.C.; ANDRADE, C.A. et al. Wermelinger, E.D. Studies on sandfly fauna (Diptera: Psychodidae) in a foci of cutaneous leishmaniasis in Mesquita. Brazil. Mem Inst Oswaldo Cruz, v.85, p.39-45, 1990.

REITHINGER, R.; DAVIES, C.R. Is the domestic dog (Canis familiaris) a reservoir host of American cutaneous leishmaniasis? A critical review of the current evidence. Am J. Trop. Med. Hyg., v.61, p.530-541, 1999.

SANTOS, G.P.L.; SANAVRIA, A.; MARZOCHI, M.C.A. et al. Prevalência da infecção canina em áreas endêmicas de leishmaniose tegumentar americana, no município de Paracambi, Estado do Rio de 
Janeiro, no período entre 1992 e 1993. Rev. Soc. Bras. Med. Trop., v.38, p.161-166, 2005.

SERRA, C.M.B.; LEAL, C.A.; FIGUEIREDO, F. et al. Leishmaniose tegumentar canina em Morada das Águias (Serra da Titirica), Maricá, Rio de Janeiro, Brasil. Cad. Saúde Pública, v.19, p.1877, 2003.

SILVA, C.A.M.; LOCH, C. Considerações acerca da paisagem urbana da cidade de Maringá - Paraná. In: CONGRESSO BRASILEIRO DE CADASTRO TÉCNICO MULTIFINALITÁRIO-COBRAC, 2006, Florianópolis. Anais... Florianópolis: UFSC, 2006. (Resumo).

SILVEIRA, T.G.V.; ARRAES, S.M.A.A.; BERTOLINI, D.A. et al. Observações sobre o diagnóstico laboratorial e a epidemiologia da leishmaniose tegumentar americana no Estado do Paraná, Sul do Brasil. Rev. Soc. Bras. Med. Trop., v.32, p.413-423, 1999.

SILVEIRA, T.G.V.; TEODORO, U.; LONARDONI, M.V.C. et al. Investigação sorológica em cães de área endêmica de leishmaniose tegumentar, no Estado do Paraná,
Sul do Brasil. Cad. Saúde Pública, v.12, p.89-93, 1996.

TEODORO, U.; ALBERTON, D.; KÜHL, J.B. et al. Ecologia de Lutzomyia (Nyssomyia) whitmani em área urbana do município de Maringá, Paraná. Rev. Saúde Pública, v.37, p.651-666, 2003.

VELÁSQUEZ, L.G.; MEMBRIVE, MEMBRIVE, N.U. et al. PCR in the investigation of canine American tegumentary leishmaniasis in northwestern Paraná State, Brazil. Cad. Saúde Pública, v.22, p.571-578, 2006.

VEXENAT, J.A.; BARRETO, A.C.; ROSA, A.C. Experimental infection of Lutzomyia whitmani in dog infected with Leishmania braziliensis braziliensis. Mem Inst. Oswaldo Cruz, v.81, p.125-126, 1986.

ZANZARINI, P.D.; SANTOS, D.R.; SANTOS, A.R et al. Leishmaniose tegumentar americana canina em municípios do norte do Estado do Paraná, Brasil. Cad. Saúde Pública, v.21, p.109$118,2005$. 